Journal of Applied Pharmaceutical Science Vol. 5 (09), pp. 153-158, September, 2015

Available online at http://www.japsonline.com

DOI: $10.7324 /$ JAPS.2015.50928

ISSN 2231-3354 (cc) BY-NC-SA

\title{
Emerging Novel Anti HIV biomolecules from marine Algae: An overview
}

\author{
Sureshbabu Nagarajan*, Manikannan Mathaiyan \\ Centre for Drug Discovery and Development, Sathyabama University, Jeppiaar Nagar, Rajiv Gandhi road, Chennai-600 119, India.
}

\begin{tabular}{l} 
ARTICLE INFO \\
\hline Article history: \\
Received on: $17 / 06 / 2015$ \\
Revised on: 10/07/2015 \\
Accepted on: $11 / 08 / 2015$ \\
Available online: $27 / 09 / 2015$ \\
\hline Key words: \\
Anti-viral compounds; \\
Marine Algae; Sulfated \\
polysaccharides; Vaccines; \\
Anti retroviral drugs
\end{tabular}

\begin{abstract}
Over the past 3 decades, despite enormous scientific advancements and developments in the field of vaccine development and drugs, HIV-1 is still posing a major challenge to human health. While development of vaccines is still clearly many years ahead, administration of FDA approved drugs leads to severe side effects and toxicity. Marine algae due to its biodiversity has been a rich source of biologically active compounds with varying degree of actions such as anti-viral, anti-cancer, anti-amyloid, anti-inflammatory and anti-oxidant properties. The primary and secondary metabolites obtained from the marine algae have shown potent anti-viral activities in vitro and in animal model. This review focus on the bioactive compounds from marine algae that have been recently identified and studied.
\end{abstract}

\section{INTRODUCTION}

HIV-1, the causative agent of AIDS, is a major human pathogen with >30 million infected people world-wide and several million deaths annually (Osman Sankoha et al., 2015). HIV is a major public health concern not only because it can't yet be prevented by vaccination, but also because those it infects are infected for life with a virus that targets their immune system making them more prone to other infections (Backus et al., 2005). According to world health organization (WHO) $\sim 35$ million peoples in the world are currently living with HIV and 36 millions AIDS related deaths till date (Shafiee et al., 2015). The vast majority of the people living with HIV are in low and middle income countries, two-thirds of them in sub-Saharan Africa (over 25 million peoples) (Figure 1) (Zhang et al., 2015). In the early years of the AIDS epidemic, people infected with the virus faced certain death, often within just a few years after infection. Initially, HIV prevention methods focused primarily on preventing the sexual transmission of HIV through behavior change. Later the biological methods of prevention such as

\footnotetext{
* Corresponding Author

Sureshbabu Nagarajan, Scientist D Centre for Drug Discovery and Development Sathyabama University, Jeppiaar Nagar, Rajiv Gandhi road, Chennai-600 119. Email: nsureshh@gmail.com
}

vaccines, microbicide, male circumcision, and pre and post exposure prophylaxis were developed (Bailey et al., 2007). For the past three decades significant progress has been made in the development of vaccines, drugs and neutralizing antibodies for HIV treatment. Despite huge effects, HIV is still posing a major health threat globally.

All the current treatment modalities against HIV offer a marginal increase in the life expectancy as observed during anti HIV treatment. Marine organism offers diverse classes of biological active compounds many of which have been translated into potential drugs for human diseases. More than $60 \%$ of the marine drugs are the secondary metabolites from algae and sponges. This review is mainly focused on bioactive compounds from marine sources for anti-viral activity.

\section{Vaccines for HIV}

The development of vaccine for HIV-1 after three decades of its discovery is clearly still many years ahead (Wang et al., 2015). Funding for developing HIV-1 vaccine was increased in last decade but now it was steadily decreasing. Developing a vaccine is a very difficult challenge mainly because

1. Lack of natural immunity to HIV

2. Frequent mutation and several subtypes of HIV

3. Lack of animal model. 


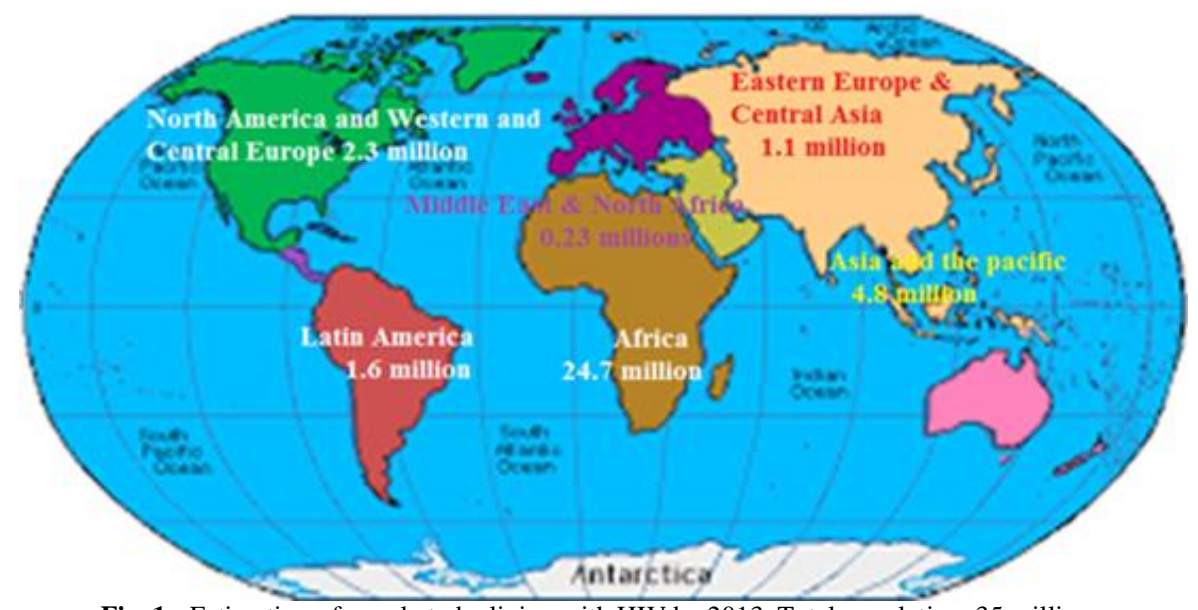

Fig. 1: Estimation of people to be living with HIV by 2013. Total population: 35 million.

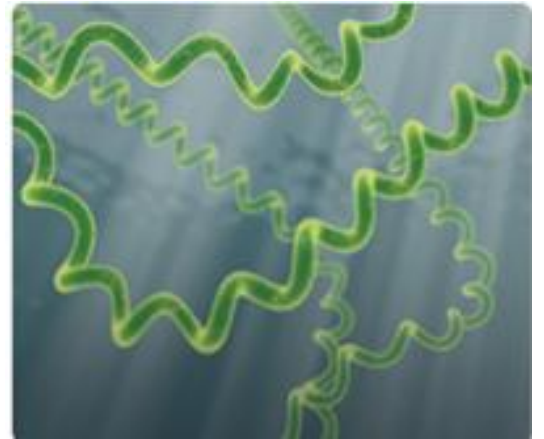

Blue-Green Algae, Spirulina Platensis, Hayashi Et Al.,(1996)

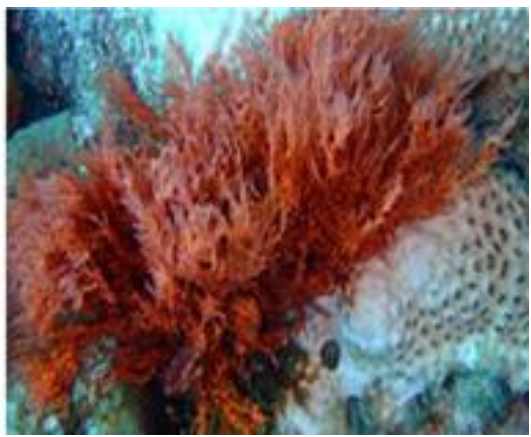

Red Algae, Griffithsia Sp Emau P Et At.,2007

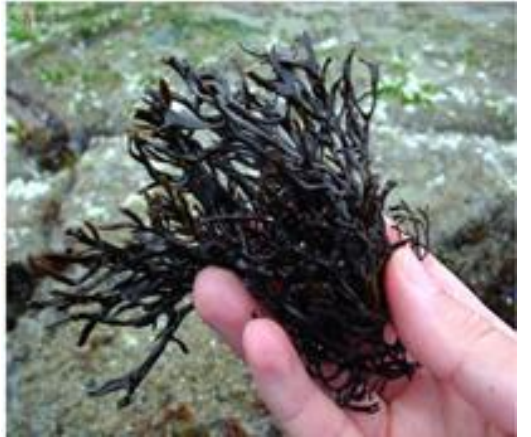

Brown Algae, Ishige Okamurae Ahn MJ Et Al., 2006

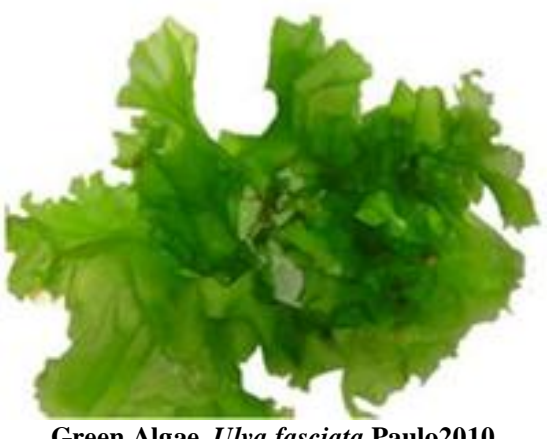

Green Algae, Ulva fasciata Paulo2010

Fig. 2. A) Blue-green Algae, Apirulina Platensis B) Red Algae, Griffithsia sp C) Brown Algae, Ishige Okamuae D) Green Algae Ulva fasciata

Since there are no suitable animal model exist till now, vaccines have to be developed in monkeys using SIV which don't have exactly the same immune effects as HIV (Velu et al., 2009). Furthermore we don't know with certainty which immune response will provide protection.

Various vaccines have been tested in clinical trials since the discovery of HIV in 1985, however after 3 decades still HIV remains a difficult target for vaccines. One of the most successful clinical trials to date has been a US Military HIV Research trial in Thailand in 2009, known as the RV144 trial, two vaccines were used together: a "prime" (the ALVAC vaccine) and a "boost" (the AIDSVAX B/E vaccine) (Peter et al., 2011). This combination vaccine was found to be safe and lowered the rate of infection by 31 percent. Another possible vaccine comes from a novel gene therapy that alters the CCR5 co-receptor permanently, preventing HIV from entering cells. A successful vaccine against HIV is yet to be developed though several come strategies are currently being evaluated.

\section{Drugs for HIV}

The treatment of HIV infection was revolutionized in the mid 1990s by the development of inhibitors for protease and reverse transcriptase two of the three essential enzymes of HIV-1. Due to structural and functional complexity of HIV, single drug is 
not sufficient to control HIV infection and therefore a multi prong attack is required. Antiretroviral therapy (ART) serves as one of the prevention strategy for HIV infection patients. People on antiretroviral therapy takes a combination of HIV medicines (called as HIV regimen) everyday. The prevention of HIV transmission from mother to child has highlighted the important use of anti retroviral drugs (Temgoua et al., 2015). Currently there are 26 FDA approved drugs from 6 mechanistic classes based on the phases of retroviral life-cycle that the drugs inhibit which are listed in Table 1. (Kinch and Patridge, 2014).

\section{Limitations of ART}

One of the major limitations of ART is its inability to act on viral reservoirs requiring adherence to lifelong treatment. Further, HIV infected individuals on ART are shown to be at elevated risk for an array of "non AIDS" conditions like liver disease, cardiovascular disease, kidney impairment, non-AIDS cancers, osteoporosis, neurocognitive decline, etc (Andrew et al., 2008). Hence, Dr. Dadachova and his researchers have used radioimmunotherapy to destroy the remaining HIV cells in the blood samples of patients treated with ART (Dadachova et al., 2006).

In spite of diverse class of drugs that targets viral enzymes at various stages of virus replication and infectivity, there still remain several powerful drivers to discover and develop new classes of HIV inhibitors. The main reasons are continued acquisition of HIV-1 resistance to currently administered antiretroviral drugs and toxicities associated with the lifelong therapy required for viral suppression (Rebecca Torres and William Lewis 2014). The discovery of compounds that inhibit the replication of HIV-1 via new mechanisms offers the best hope of generating drugs that are active against all HIV-1 variants in the clinic. In principle, viral mutations conferring resistance to any existing drug classes would not confer cross-resistance to drugs targeting a new mechanism.

\section{Natural products from marine sources for anti-viral activity}

Natural products have been the source of most of the active ingredients of medicines (Newman et al., 2012; Chin et al., 2006; Fischbach \& Clardy, 2007). Almost 50\% of the drugs approved since 1994 are based on the natural products including marine sources. Many marine organisms live in challenging and extreme conditions such as low temperature and high pressure, and in adapting to such conditions they produce a wide variety of primary and secondary metabolites which cannot be present in other organisms (Lordan et al., 2011; Ponnambalam et al., 2013). Nearly $58 \%$ of the marine bioactive compounds have been extracted from algae (25\%) and sponges (33\%). Marine algae due to its biodiversity is a rich natural source of biologically active compounds such as polyphenols, sulphated polysaccharides, terpenes, alkaloids, carotenoids, sterols, proteins and antioxidants (Hamed et al., 2015).

Marine algae are classified into four major groups 1) Blue-green algae (Cyanobacteria) 2) Green Algae (Chlorophyta) 3) Red Algae (Rhodophyta) and 4) Brown Algae (Phaeophyta), based on the chloroplast present in them. These classes of algae are ubiquitous and its primary and secondary metabolites have shown activities against anti-viral, anti-cancer, anti-bacterial and antifungal.

\section{Cyanobacteria; Blue-Green Algae}

Cyanobacteria are Gram-negative prokaryotes; obtain their energy through photosynthesis with autotrophy as their dominant mode of nutrition. They are ubiquitous, widespread distribution in both aquatic and terrestial zones including several types of challenging and extreme environmental conditions and stress. They produce different classes of primary and secondary metabolites to adapt themselves to challenging environments. Interest on cyanobacteria as a possible source of pharmaceutical and bioactive compounds emerged within the last 20 years and several compounds of interest which are quite unique and novel to Cyanobacteria have been identified. A variety of secondary metabolites belonging to different chemical groups, such as alkaloids, macrolides, glycosides, peptides etc. have been found to possess different bioactivities (Giromes et al., 1989 and Lau AF et al, 1993). Marine Cyanobacterial being photoautotrophic in nature, mass cultivation of the organism that could produced cost effective bioactive metabolites. Furthermore, Cyanobacteria are known for containing novel bioactive compounds including toxins which may have wide pharmaceutical applications. The table 2 represents the bioactive molecules from Cyanobacteria that have shown activity against HIV life cycle.

Table 1: FDA approved drugs for inhibition of HIV-1 replication and infections. These drugs targets viral genome, reverse transcriptase, protease, viral coat protein gp120 and integrase.

\begin{tabular}{|c|c|c|c|c|}
\hline $\begin{array}{c}\text { Nucleoside reverse } \\
\text { transcriptase inhibitors } \\
\text { (NTRI's) }\end{array}$ & $\begin{array}{l}\text { Non-nucleoside reverse } \\
\text { transcriptase inhibitors } \\
\text { (NNTRI's) }\end{array}$ & Protease inhibitors & Entry inhibitors & HIV integrase inhibitors \\
\hline Zidovudine & Nevirapine & Saquinavir & Enfuvirtide & Raltegravir \\
\hline Didanosine & Delavirdine & Indinavir & Maraviroc & Elvitegravir \\
\hline Stavudine & Efavirenz & Ritonavir & & Dolutegravir \\
\hline Lamivudine & Etravirine & Nelfinavir & & \\
\hline Abacavir & Rilpivirine & Amprenavir & & \\
\hline Tenofovir & & Lopinavir/ritonavir & & \\
\hline Combivir & & Atazanavir & & \\
\hline Trizivir & & Fosamprenavir & & \\
\hline Emtricitabine & & Tipranavir & & \\
\hline Truvada & & Darunavir & & \\
\hline Epzicom & & & & \\
\hline
\end{tabular}




\section{Brown Algae}

Brown algae are exclusive to the marine habitat. The body of all brown algae is termed a thallus, indicating that it lacks the complex xylem and phloem of vascular plants. The brown algae are rich in photosynthetic pigments (chlorophyll a \& c, carotene, xanthophylls and fuxoxanthin) and polysaccharides that possess many biological activities (Ruperez and Saura-Calixto 2001; Siriwardhana et al., 2004). The photosynthetic products of the brown algae are laminarian and mannitol. Food reserves of brown algae are typically complex polysaccharides, principally laminarin, (others - galactans, fucoidan, laminarin, alginates) and higher alcohols (Ferreira et al., 2012).

The various biological properties exhibited by brown algae include immune modulation (Raghavendran et al., 2011); anti-inflammation (Islam et al., 2013); antiviral (Sinha et al., 2010); antioxidative (Balboa et al., 2013); vasodilation (Park et al., 2008); anticoagulant (Arivulsevan et al., 2011); antitumor (Khanavi et al., 2010); anti-vasculogenic (Dias et al 2008); antiherpetic (Lee et al., 2010) anti lipidemic (Guangling Jiao et al., 2011), and hepato-protection (Josephine et al., 2008). Brown algae have potential for therapeutic application because they are taxonomically diverse, largely productive, biologically active and chemically unique, thus offering a great scope for discovery of drugs from the ocean. Table 3 represents the anti-viral compounds extracted from brown algae that targets virus at different level.

\section{Red Alage}

Several bioactive compounds have been identified from the red marine algae and available in markets as anti-viral foods in assisting body's specific immune regulatory response. Their sulphated polysaccharides have shown promising activity towards HIV, Ebola, Hepatitis C and H5N1 virus. Current research on red marine algae in the family of Dumontiaceae suggests a breakthrough in the discovery of natural immunomodulatory and antiviral agents.

Further the sulphated polysaccharides extracted from red marine algae suppressed retroviral replications and inhibited viral reverse transcriptases. Table 4 represents anti-viral compounds that have shown promising inhibitory activity against many viruses at entry and replication steps.

\section{Green Algae}

The green algae are a large and diverse group of photosynthetic eukaryotes, with more than 7000 species growing in a variety of habitats. Green algae are important components of marine, freshwater and terrestrial ecosystems. Several screening studies have been carried out over few decades with the aim to discover new antibiotic or cytotoxic metabolites (Mayer et al., 2004; 2007).

Sulphated polysaccharide extracts collected by maceration and decoction from Green algae Ulva fasciata possessed $100 \%$ inhibitory activity against human metapneumovirus (HMPV). The results from this study have shown the biomolecules acts against two possible mechanisms, virucidal and inhibition of cell entry (Paulo 2010). Further, Ulva fasciata produces a novel sphingosine derivative has been found to have antiviral activity in vivo (Garg et al., 1992). Caulerpa racemosa, collected from the South China Sea showed potent inhibition of herpes simplex virus type 1 (HSV-1) and Coxsackie virus B3 (Cox B3). A Sulfoquinovosyldiacyl-glycerol (SQDG) exhibited an excellent antiviral effect against HSV-2, with a 50\% inhibitory concentration (IC50) of $15.6 \mu \mathrm{g} \mathrm{ml}^{-1}$ against both standard and clinical strains of HSV-2, but showed only moderate antiviral effects against HSV-1 and Cox B3 (Yue-Wei Guo 2014).

Table 2. Biomolecules from Blue-green algae (Cyanobacteria) and its inhibitory activity on viral targets and life cycle.

\begin{tabular}{|c|c|c|c|}
\hline Bioactive molecules & Cyanobacteria & Virus Targets ( within the replication cycle) & References. \\
\hline Sulfolipids & Lyngbya majuscula & Virus particles, infectivity, entry & Boyed MR et al. (1997) \\
\hline Spirulan & Spirulina Platensis & $\begin{array}{l}\text { HIV-1 and HIV-2 (inhibit reverse transcriptase) HSV, } \\
\text { influenza }\end{array}$ & Hayashi et al. (1996) \\
\hline Cyanovirin $-\mathrm{N}$ (Hypericin) & Nostoc ellipsosporum & $\begin{array}{l}\text { Interacts with mannose groups of envelope glycoproteins gp } \\
120 \text { and blocks its interaction with target cell receptors) }\end{array}$ & Dey et al.(2000) \\
\hline Scytovirin & Scytonema varium & $\begin{array}{l}\text { Interacts with oligosaccharides containing alpha1-2 alpha1-2, } \\
\text { alpha 1-6 tetramannose units of envelope glycoproteins, } \\
\text { gp120, gp160, gp41 }\end{array}$ & Rahul Kunwar Singh et al. (2011) \\
\hline Sulfoglycolipid & Scytonema sp. & Inhibits RT and DNA Polymerases & Loya et al. ((1998) \\
\hline Sulfated polysaccharides & Aghardhiella tenera & Virus adsorption & $\begin{array}{l}\text { Rahul Kunwar Singh et al. (2011) } \\
\text { Boyed MR et al. (1997) }\end{array}$ \\
\hline
\end{tabular}

Table 3: Biomolecules from Brown Algae and its inhibitory activity on viral targets and life cycle.

\begin{tabular}{|c|c|c|c|}
\hline Bioactive molecules & Brown Algae & $\begin{array}{c}\text { Virus Targets } \\
\text { ( within the replication cycle) }\end{array}$ & References \\
\hline Water extract & Cystoseira myrica & herpes simplex virus type 1 (HSV-1) & Keivan Zandi 2007 \\
\hline Aqueous/Ether extract (Diterpenes) & Dictyota Pfaffii Schnetter & HSV-1 1 & Jussara etal. 2003 \\
\hline Sulphated polysaccharide & Padina pavonia & HAV and HSV & $\begin{array}{l}\text { Sahera F. Mohamed Fatimah } \\
\text { A. Agili et al., } 2013\end{array}$ \\
\hline Diphlorethohydroxycarmalol & Ishige Okamurae & HIV-1 reverse transcriptase and integrase & Ahn MJ et al. 2006 \\
\hline Galactofucan Fucose, galactose & Adenocystis utricularis & anti-HIV-1 activity in vitro & Trinchero etal., 2009 \\
\hline Sulfated polymannoroguluronate Mannuronate & Dictyota mertensii & HIV-1 entry & Meiyu etal. 2003 \\
\hline Sulfated polymannuronate Mannuronate & Lobophora variegate & HIV-1 entry & Stephan Kremb etal. 2014 \\
\hline Sulfated fucans Fucose & Fucus vesiculosus & HIV-1 reverse transcriptase & Queiroz et al. \\
\hline
\end{tabular}


Table 4: Biomolecules from Red algae and its inhibitory activity on viral targets and life cycle.

\begin{tabular}{|c|c|c|c|}
\hline Bioactive molecules & Red Algae & Virus Targets ( within the replication cycle) & References. \\
\hline Bromophenols & Polysiphonia morrowii & $\begin{array}{l}\text { Fish pathogenic viruses, infectious hematopoietic } \\
\text { necrosis virus and infectious pancreatic necrosis virus }\end{array}$ & Kim et al. 2011 \\
\hline carrageenan & Gigartina & Herpes simplex virus types 1 (HSV-1) and 2 (HSV-2) & Su-Yeun Kim et al., 2011 \\
\hline Griffithsin & Griffithsia sp & $\begin{array}{l}\text { GRFT Cellular intrusion of the HIV-1, Ebola, SARS, } \\
\text { hepatitis C and H5N1 virus }\end{array}$ & $\begin{array}{l}\text { Philip Meuleman et al. } \\
\text { 2011; Emau P et al., } 2007 .\end{array}$ \\
\hline Sulphated galactans Galactose, xylose & $\begin{array}{l}\text { Grateloupia filicina, } \\
\text { Grateloupia longifolia }\end{array}$ & HIV-1 inhibitory activity & Wang et al., 2007 \\
\hline Sulfated glucuronogalactan Galactose & Schizymenia dubyi & HIV-1 inhibitory activity & Bourgougnon et al. 1996 \\
\hline
\end{tabular}

\section{CONCLUSION}

The algae derived natural biomolecules has several advantages, such as availability, relatively low production cost and low cytotoxicity. Recent studies demonstrated that biomolecules and extracts from four major classes of marine algae targets HIV, HSV, fish virus, Ebola, SARS, hepatitis C and H5N1 enzymes and inhibits viral entry and replication. These compounds can be used alone or in combination with other ART drugs for anti-viral infections. Although these biomolecules have shown promising anti-viral activity in vitro and in animal models, further studies by chemoinformatics and identification of target binding sites will improve our knowledge to investigate their anti-viral activities in human.

\section{REFERENCES}

Bedia KK, Elçin O, Seda U, Fatma K, Nathaly S, Sevim R, Dimoglo A. Synthesis and characterization of novel hydrazide-hydrazones and the study of their structure-antituberculosis activity. Eur J Med Chem, 2006; 41: 1253-1261.

Ahn MJ, Yoon KD, Kim CY et al. Inhibitory activity on HIV-1 reverse transcriptase and integrase of a carmalol derivative from a brown Alga, Ishigeokamurae. Phytother Res. 2006; 20: 711-713.

Andrew NP, James N and Jens DL. The Role of HIV in Serious Diseases than AIDS. AIDS. 2008; 30: 2409-2418.

Arivulsevan N, Radhiga M, Anantharaman P. In vitro antioxidant and anticoagulant activities of Sulphated Polysaccharides from Brown Seaweed (Turbinaria ornata) (Turner) J.Agardh. Asian J Phar Biol Res. 2011; 1: 232-239

Bailey R, Moses S, Parker, C. et al. Male circumcision for HIV prevention in young men in Kisumu, Kenya: a randomized controlled trial. Lancet 2007; 369: 643-656.

Balboa EM, Conde E, Moure A, Falqué E, Domínguez H. In vitro antioxidant properties of crude extracts and compounds from brown algae. Food Chem., 2014; 13: 1764-1785.

Barton C, Kouokam JC, Lasnik AB et al. Activity of and effect of subcutaneous treatment with the broad-spectrum antiviral lectin griffithsin in two laboratory rodent models. Antimicrobial Agents and Chemotherapy. 2014; 58: 120-7.

Bhakuni S, Rawat N. Bioactive Marine Natural Products. Springer-online. 2005; 351-365

Bourgougnon N, Lahaye M, Quemener B, Chermann JC et al. Annual variation in composition and in vitro anti-HIV-1 activity of the sulfated glucuronogalactan from Schizymenia dubyi (Rhodophyta, Gigartinales). Journal of Applied Phycology. 1996; 8: 155-161.

Boyd MR, Gustafson KR, McMahon JB et al. Discovery of cyanovirin-N, a novel human immunodeficiency virus-inactivating protein that binds viral surface envelope glycoprotein gp120: potential applications to microbicide development. Antimicrob Agents Chemother. 1997; 41: 1521-1530.

Chin YW, Balunas MJ, Chai HB, Kinghorn AD. Drug discovery from natural sources. AAPS J. 2006; 8: E239-E253.
Dey B, Lerner D L, Lusso P, Boyd M R, Elder J H, Berger E A. Multiple antiviral activities of cyanovirin-N: blocking of human immunodeficiency virus type 1 gp120 interaction with CD4 and coreceptor and inhibition of diverse enveloped viruses. J Virol. 2000; 74: $4562-4569$.

Dias PF, Siqueira JM, Vendruscolo LF et al. A polysaccharide isolated from the brown seaweed Sargassum stenophyllum exerts antivasculogenic effects evidenced by modified morphogenesis, Microvasc. Res. 2008; 75: 34-44.

Ekaterina D, Mahesh CP, Sima T et al. Targeted Killing of Virally Infected Cells by Radiolabeled Antibodies to Viral Proteins. PLoS Med. 2006; 3: e427.

Emau P, Tian B, O'keefe BR. et al. "Griffithsin, a potent HIV entry inhibitor, is an excellent candidate for anti-HIV microbicide". J. Med. Primatol. 2007; 36: 244-53.

Fischbach MA, Clardy J. One pathway, many products. Nat Chem Biol. 2007; 3: 353-5.

Garg HS, Sharma T, Bhakuni DS, Pramanik BN, Bose AK. An antiviral sphingosine derivative from green alga Ulva fasciata. Tetrahedron lett. 1992; 33: 1641-1644.

Giromes R, Jofre JT, Bosch A. Isolation of marine bacteria with antiviral properties. Can. J. Microbiol. 1989; 35: 1015-1021.

Hayashi K., et al. An Extract from Spirulina Platensis is a Selective Inhibitor of Herpes Simplex Virus Type 1 Penetration into HeLa Cells. Phytotherapy Research. 1993; 7: 76-80.

Hayashi T, Hayashi K, et al, American Chemical Society and American Society of Pharmacognosy. Calcium Spirulan, an Inhibitor of Enveloped Virus Replication, from a Blue-Green Alga Spirulina Platensis. Journal of Natural Products, 1996; 59: 83-87,

Imen $\mathrm{H}$, Fatih $\mathrm{O}$, Yesim $\mathrm{O}$, Joe M. Marine Bioactive Compounds and Their Health Benefits: A Review Comprehensive in Food Science and Food Safety. 2014; 14: 446-465.

Islam MN, Ishita IJ, Jin SE, et al. Anti-inflammatory activity of edible brown alga Saccharina japonica and its constituents pheophorbide a and pheophytin a in LPS-stimulated RAW 264.7 macrophage cells. Food and Chemical Toxicology. 2013; 55: 541-548.

Jiao G, Yu G, Zhang J, Ewart S. Chemical structures and bioactives of sulfated polysaccharides from marine algae. Mar. Drugs; 2011; 9: 196-223.

Josephine A, Nithya K, Amudha G, et al. Role of sulphated polysaccharides from Sargassum wrightii in Cyclosporine A-induced oxidative liver injury in rats, BMC Pharmacol. 2008; 8: 64-68.

Jussara P, Barbosa BG, Fleury BAP, et al. Natural products as antifoulants in the Brazilian brown alga Dictyota pfaffii (Phaeophyta, Dictyotales). Biochemical Systematics and Ecology 2007; 35: 549e553.

Keivan Z, Moradali F, Parisa P, Kohzad S. Evaluation of in vitro antiviral activity of a brown alga (Cystoseira myrica) from the Persian Gulf against herpes simplex virus type 1. 2007; 6: 25112514

Khanavi M, Nabavi M, Sadati N et al. Cytotoxic activity of some marine brown algae against cancer cell lines, Biology Research. 2010; 43: 31-37

Kim SY, Kim SR, Oh MJ, Jung SJ, Kang SY. In vitro antiviral activity of red alga, Polysiphonia morrowii extract and its bromophenols against fish pathogenic infectious hematopoietic necrosis virus and infectious pancreatic necrosis virus. Journal of Microbiology. 2011; 49: 102-106. 
Kinch MS, Patridge E. An analysis of FDA-approved drugs for infectious disease: HIV/AIDS drugs. Drug Discov Today. 2014; 19: 1510 3.

Kyoko H, Toshimisu H, and Ichiro K. AIDS Research and Human Retroviruses. 1996; 12: 1463-1471

Lee JB, Koizume S, Hayashi K, Hayashi T, Structure of rhamnan sulfate from the green alga Monostroma nitidum and its antiherpetic effect, Carbohyd.Polym. 2010; 87: 572-577.

Loya S, Reshef V, Mizrachi E, Silberstein C, Rachamim Y, Carmeli S, Hizi A. The inhibition of the reverse transcriptase of HIV-1 by the natural sulfoglycolipids from cyanobacteria: contribution of different moieties to their high potency. J Nat Prod. 1998; 61: 891-895

Meiyu G, Fuchuan X, Xianliang L, Jing Y, Zuowei Y, Huashi G. The potential molecular targets of marine sulfated polymannuroguluronate interfering with HIV-1 entry. Interaction between SPMG and HIV-1 rgp120 and CD4 molecule. Antiviral Research 2003; 59: 127-135.

Newman DJ, Cragg GM. Natural products as sources of new drugs over the 30 years from 1981 to 2010 . Journal of natural products. 2012; 75: 311-35.

Osman S, Samuelina A, Bongiwe N and Mark W. Prevention, treatment and future challenges of HIV/AIDS: A decade of HIV \& AIDS. 2015; 14: 1-8. Review

Park BY, Kwon SC, Park GB, Ham J. Vasodilation effect of farnesylacetones, active constituents of Sargassum siliquastrum on the basilar and carotid arteries of rabbits, Bioorg. Medicinal Chem. Lett. 2008; 18: 6324-6326.

Paulo S. Antiviral Activity of the green marine alga Ulva fasciata on the replication of human metapneumovirus. Rev. Inst. Med. trop. 2010; 52: 3-10.

Peter BG, James OB, et al. Statistical Interpretation of the RV144 HIV Vaccine Efficacy Trial in Thailand: A Case Study for Statistical Issues in Efficacy Trials. The Journal of Infectious Diseases 2011; 203: 969-75

Philip M, Anna A, Sandrine B et al. Griffithsin Has Antiviral Activity against Hepatitis C Virus. Antimicrob Agents Chemother. 2011; 55: 5159-5167.

Ponnambalam S, Elangovan D, Thirunavukkarasu T, Jutta P. Bioactive natural products from marine angiosperms: abundance and functions. Review Nat. Prod. Bioprospect. 2013; 3: 129-136.

Queiroz KCS, Medeiros VP, Queiroz LS, et al. Inhibition of reverse transcriptase activity of HIV by polysaccharides of brown algae. Biomed Pharmacother 2008; 62: 303-307.

Raghavendran HR, Sathivel A, Devaki T. Effect of Sargassum polycystum (Phaeophyceae)-sulphated polysaccharide extract against acetaminophen-induced hyperlipidemia during toxic hepatitis in experimental rats. Mol Cell Biochem. 2005; 276: 89-96.

Rahul KS, Shree PT, Ashwani KR, Tribhuban MM. Cyanobacteria: an emerging source for drug discovery. The Journal of Antibiotics. 2011; 64: 401-412

Rebecca AT and William L. Pathogenetic role of therapeutic side effects Laboratory Investigation. Aging and HIV/AIDS. 2014; 94: $120-128$.
Ruperez P, Saura-Calixto F. Dietary fibre and physichemical properties of edible Spanish seaweeds. Eur. Food Res. Technol. 2001; 212: 349-354

SaoundeTemgoua EM, Nkenfou CN, Zoung-Kanyi Bissek AC, et al. HIV-1 Early Infant Diagnosis is an Effective Indicator of the Prevention of Mother-to-Child Transmission Program Performance: Experience from Cameroon. Curr HIV Res. 2015.

Shafiee H, Wang S, Inci F, Toy M, Henrich TJ, Kuritzkes DR, Demirci U. Emerging technologies for point-of-care management of HIV infection. Annu Rev Med. 2015; 66: 387-405.

Sinéad L, Paul R, Catherine S. Marine Bioactives as Functional Food Ingredients: Potential to Reduce the Incidence of Chronic Diseases. Mar Drugs. 2011; 9: 1056-1100.

Sinha S, Astani A, Ghosh T, Schnitzler P, Ray B. Polysaccharides from sargassum tenerrimum: Structural features, chemical modification and anti-viral activity. Phytochemistry, 2010; 71: 235-242.

Stephan K, Markus H, Birgit K, Horst W, Christian W, Martha S, Christian RV, Ruth B Aqueous Extracts of the Marine Brown Alga Lobophora variegata Inhibit HIV-1 Infection at the Level of Virus Entry into Cells PLoS One. 2014; 9: e103895.

Turner JA. Sulfated polysaccharides from brown seaweed (Turbinaria ornata) Asian J Pharmaceutic. Biol Res. 2011; 1: 232-239.

Su-Yeon K, Eun CY, Sung MB, Hwan SY. Complete mitochondrial genome of the marine red alga Grateloupia angusta (Halymeniales). Mitochondrial DNA, Early Online. 2013: 1-2.

Trinchero J., Ponce NMA., Córdoba OL., Flores ML, Pampuro S, Stortz CA, et al. The AAPS journal 2009; 8: E239-53.

Velu V, Titanji K, Zhu B et al. Nature Enhancing SIV-specific immunity in vivo by PD-1 blockade. 2009; 12: 206-10.

Wang HB, Mo QH, Yang Z. (2015) HIV vaccine research: the challenge and the way forward. J Immunol Res., 2015:503978.

Wang SC, Bligh, SWA, Shi SS, Wang ZT, et al. Structural features and anti-HIV-1 activity of novel polysaccharides from red algae Grateloupia longifolia and Grateloupia filicina. International journal of Biological Macromolecules 2007; 41: 369-375.

Wen-Fei H, Yan L, Mei-Tang F, Margherita G, Ernesto M, et al. New isoquinolinequinone alkaloids from the South China SeanudibranchJorunna funebrisand its possible sponge-prey Xestospongiasp. Fitoterapia 2014; 96: 109-114.

Zhang J, Jemmott JB 3rd, Heeren AG. Sub-Saharan African University Students' Beliefs about Abstinence, Condom Use, and Limiting the Number of Sexual Partners. Behav Med. 2015.

\section{How to cite this article:}

Sureshbabu Nagarajan and Manikannan Mathaiyan., Emerging Novel Anti HIV biomolecules from marine Algae: An overview. J App Pharm Sci, 2015; 5 (09): 153-158. 